\title{
KEUNGGULAN SUB SEKTOR PERIKANAN DAN PARIWISATA BAHARI DI BELITUNG
}

\section{Performance of Fisheries and Tourism Sub Sectors in Belitung}

\author{
*Mira dan Risna Yusuf \\ Balai Besar Riset Sosial Ekonomi Kelautan dan Perikanan \\ Gedung BRSDM KP I Lt. 4 \\ Jalan Pasir Putih Nomor 1 Ancol Timur, Jakarta Utara, Indonesia \\ Telp: (021) 64711583 Fax: 64700924 \\ Diterima tanggal: 13 April 2019 Diterima setelah perbaikan: 28 Mei 2019 \\ Disetujui terbit: 30 Juni 2019
}

\begin{abstract}
ABSTRAK
Tujuan dari penelitian adalah mengukur kinerja perikanan dan pariwisata bahari dalam struktur perekonomian Belitung, apakah sektor tersebut memiliki keuggulan komparatif, termasuk pada sektor unggulan/prospektif/berkembang/potensial/terbelakang. Penelitian dilakukan pada tahun 2016 di Kabupaten Belitung. Metode yang digunakan dalam penelitian ini adalah pergeseran struktur perekonomian. Hasil pengolahan data mengindikasikan, pertama dari sektor perikanan dan pariwisata termasuk pada sektor yang tidak memiliki keunggulan komparatif dan daya saing karena memiliki nilai komponen pangsa wilayah negatif $(-2,58 \%$, dan $-1,16 \%)$. Kedua, sektor wisata bahari termasuk pada kategori sektor yang mengalami pertumbuhan progresif $(3,25 \%)$ yang diindikasikan dengan dengan nilai pergeseran bersih yang positif. Perlambatan pertumbuhan terjadi pada sektor yang dulunya tumpuan perekonomian Belitung (perikanan dan pertambangan) yang diindikasikan dengan nilai pergeseran bersih negatif $(-11,16 \%)$. Ketiga, jika dilihat dari rasio indikator pertambahan pertumbuhan masing-masing sektor adalah wisata $(113 \%)$, dan perikanan $(112 \%)$, mengindikasikan kedua sektor ini termasuk yang produktif dan potensial dan tidak terjadi ketimpangan sektor. Keempat, jika dilihat dari profil sektor dalam kuadran, sektor wisata bahari terletak pada kuadran 3 yang berarti termasuk sektor agak mundur. Sedangkan sektor perikanan termasuk pada kuadran 4 yang mengindikasikan sektor ini masuk sektor yang mundur. Di Belitung terjadi pergeseran perekonomian, yang awalnya mengandalkan sektor primer (perikanan dan pertambangan), beralih ke sektor tersier (industri dan wisata bahari). Diharapkan pemerintah, mendukung mata pencarian alternatif selain sektor pertambangan dan perikanan, seperti sektor wisata bahari. Salah kendala pengembangan mata pencarian alternatif ini adalah perbedaan orientasi usahanya, dimana awalnya masyarakat menggeluti usaha ekstrasi (fisik) dan beralih menggeluti usaha jasa wisata (pelayanan).
\end{abstract}

Kata Kunci: wisata bahari; perikanan; sektor; indikator; pergeseran bersih

\begin{abstract}
The objective of this research was to analyze performance of fisheries and marine tourism sector in Belitung Regency. The analysis was to measure whether the sector has comparative advantage, prospective, developed, potential or underdeveloped condition. The research was conducted in 2016 at Belitung Regency. Data were analyzed by economic structure shift analysis. The results indicated a number of findings. First, fisheries and tourism sector did not have comparative advantage and competitiveness due to its negative regional share component (- 2.58\%, and $-1.16 \%)$. Second, marine tourism sector had progressive growth (3.25\%) indicated from positive net shift component. Instead, despite the fact that fisheries and mining were the base sector of Belitung Regency, they experienced deceleration of growth indicated by a negative net shift component $(-11,16 \%)$. Third, a growth rate ratio analysis indicated that fisheries and marine tourism are productive and potential sectors because they had a positive growth rate ratio of $112 \%$ and $113 \%$. Fourth, the marine tourism sector was in quadrant 3 , it means that marine tourism was a fairly declining sector. Fisheries sub sector was in quadrant 4, it means that it was a declining sector. There was an economic shift in Belitung from primary sector (fisheries and mining) to tertiary sector (industry and marine tourism). The government was expected to create alternative livelihoods other than mining and fisheries such as marine tourism. However, problem occurred in the difference of business orientation from physical business to industrial and tourism services.
\end{abstract}

Keywords: marine tourism; fisheries; sector; indicator; net shift 


\section{PENDAHULUAN}

Menurut Hustin (2017) sektor maritim Indonesia sampai saat ini terbilang belum dapat dimanfaatkan secara optimal. Bahkan, itu pun masih terfokus pada bidang perikanan saja, karena tidak dapat dipungkiri bahwa ketika mayoritas masyarakat Indonesia berbicara maritim maka yang terlintas di benaknya adalah perikanan. Padahal kekayaan maritim tidak hanya sektor perikanan juga ada sektor wisata bahari. Artinya, potensi maritim terutama yang dimiliki oleh Pulau-pulau kecil tidak hanya untuk pengembangan sektor perikanan, tapi juga untuk pengembangan sektor wisata. Menurut Mudzakir (2008) Secara umum sektor perikanan mempunyai nilai keterikatan ke belakang lebih besar dibandingkan dengan ke depan, baik pada keterkaitan langsung maupun tidak langsung. Sedangkan sektor wisata sebaliknya, dimana keterikatan ke depan lebih besar ketimbang keterikatan ke belakang.

Di beberapa wilayah yang awalnya perekonomian bertumpu pada sektor perikanan, sudah didominasi oleh pengembangan kearah sektor wisata. Terutama terjadi pada wilayah pulaupulau kecil yang menjadi kawasan pengembangan sektor wisata. Seperti Sumbawa misalnya, sektor wisata bahari mengalami laju pertumbuhan di atas rata-rata sebesar $166 \%$, sedangkan sektor perikanan hanya mencatat pertumbuhan sebesar 138\% (Mira \& Witomo, 2016). Bahkan di Kepulaun Seribu, sub sektor wisata bahari mampu bersaing dengan sektor migas. Sumber pertumbuhan ekonomi Kepulauan Seribu tanpa Migas paling besar berasal dari sektor hotel dan restoran (wisata) sebesar $2,84 \%$. Apabila dihitung dengan Migas, ternyata sumber pertumbuhan ekonomi paling besar juga diciptakan oleh sektor hotel dan restaurant (wisata) yaitu sebesar $0,40 \%$ (Mira, 2013)

Secara ekonomi pengembangan sektor wisata berdampak pada peningkatan devisa, pendapatan asli daerah, dan penyerapan tenaga kerja. Sedangkan secara kewilayahan menurut Abdillah (2016), pengembangan sektor wisata kepariwisataan Indonesia memiliki karakter multisektor dan lintas regional secara konkret akan mendorong pembangunan infrastruktur menggerakkan arus investasi dan pengembangan wilayah. Secara sosial, pengembangan sektor wisata dapat meningkatakan kesejahteraan masyarakat sebagai imbas dari peningkatan pendapatan masyarakat.
Sektor wisata memiliki multiplier effect, dimana hotel dan restoran membutuhkan tenaga kerja yang pada akhirnya menyerap pengangguran di suatu wilayah. Dampak selanjutnya selain menyerap penganguran suatu wilayah pengembangan sektor wisata menyebabkan peningkatan pendapatan masyarakat. Multiplier effect lainnya menurut Razak, Suzana \& Kapantaouw (2017). Semakin banyak wisatawan yang datang maka akan semakin banyak devisa yang diterima dan pada akhirnya akan mendorong pembangunan sarana dan prasarana wisata lainnya.

Banyak beberapa wilayah pulau kecil, yang tadinya perekonomian bertumpu pada sektor perikanan lama kelamaan mengandalkan sektor wisata. Beberapa wilayah yang sektor wisata menjadi destinasi dunia, seperti beberapa pulau di Mediterania, terjadi transformasi ekonomi yang tadinya mengandalkan perekonomiannya pada sektor perikanan berubah mengandalkan sektor wisata. Di Eropa saja yang bukan negara kepulauan, kontribusi sektor wisata terhadap PDB Eropa adalah lebih dari $5 \%$, dimana $7 \%$ dari sektor yang berkaitan dengan sektor wisata adalah sangat penting bagi beberapa pulau.

Menurut (Budianto, Susilo \& Indrayani, 2013) salah satu menjadi kendala dalam pengembangan wisata di wilayah yang tadinya menggantungkan hidupnya pada sektor perikanan, adalah masalah keterampilan masyarakat. Sektor perikanan adalah sektor primer, dimana tergantung pada sumberdaya kelautan dan perikanan. Keahlian pada sektor perikanan biasanya diperoleh dari turun temurun. Sedangkan sektor wisata adalah sektor jasa, dimana keahlian yang dibutuhkan oleh sektor ini belum bisa dipenuhi oleh nelayan. Ada pun tujuan dari penulisan makalah ini adalah menganalisis sejauh mana transformasi perokonomian (dari sektor perikanan (primer) ke sektor jasa di Kepulauan Belitung.

\section{METODOLOGI}

\section{Waktu dan Lokasi Penelitian}

Penelitian ini dilakukan pada tahun 2016. Ada pun lokasi penelitian pada wilayah pulau-pulau kecil yang diduga mengalami transformasi ekonomi. Wilayah tersebut adalah Kabupaten Belitung yang berada di propinsi Bangka Belitung. Berdasarkan wawancara dengan Bidang Perekonomian di Bappeda Belitung terungkap bahwa sektor wisata 
berkembang setelah sebelumnya sektor yang berkembang adalah sektor pertambangan dan sektor perikanan.

\section{Jenis dan Sumber data}

Data yang digunakan dalam penelitian ini adalah data sekunder dan data primer. Data sekunder meliputi sektor-sektor ekonomi yang diteliti, perubahan sektor ekonomi wilayah yang diteliti, perubahan sektor nasional, pertumbuhan nasional sektor yang diteliti pada wilayah yang menjadi lokasi penelitian, bauran sektor tersier dan jasa, keuggulan kompetitif sektor yang diteliti. Selain itu juga digunakan data primer untuk menguatkan hasil olahan analisis, dimana narasumber yang berkompentensi untuk memverifikasi adalah Badan Perencanaan Daerah Bidang Perekonomian, Dinas Kelautan, dan Dinas Pariwisata.

\section{Metodologi Analisis Data}

Analisis pergeseran struktur perekonomian awalnya dilakukan untuk melihat transformasi ekonomi yang terjadi di negara berkembang. Menurut Todaro \& Smith, (2004). Pada negara berkembang biasanya awal struktur perekonomian didominasi oleh sektor primer, dan lama kelamaan berkembang sektor sekunder dan tersier (industri dan jasa). Hal ini juga sering terjadi pada wilayah pulau-pulau kecil yang awalnya didominasi oleh sektor perikanan (primer) dan berkembang sektor tersier (jasa) dalam hal ini sektor wisata. Dalam lokasi penelitian pada makalah ini akan dianalisis perubahan struktur perekonomian dari sektor primer ke sektor jasa (wisata bahari) di Pulau Belitung.

Teori pergeseran struktur perekonomian menurut Hasani (2010) dibagi berdasarkan pertama teori Fei Ranis, dimana pergeseran struktur perekonomian suatu wilayah yang bertransformasi dengan adanya transfer tenaga kerja dari sektor pertanian ke sektor industri. Kedua teori W. Arthur Lewis, dimana mengungkapkan transformasi ekonomi yang dari sub sisten ke sektor industri pada suatu wilayah. Ketiga teori Chenery dimana menjelaskan perubahan struktur perekonomian dari negara berkembang yang mengalami transformasi dari pertanian tradsional ke sektor industri.

Pendekatan transformasi ekonomi suatu wilayah ini biasanya mengunakan dua pendekatan. Pendekatan pertama menurut Abidin (2015) adalah pendekatan Esteban - Marquillas, pada pendekatan ini membagi pertumbuhan sebagai perubahan variabel wilayah seperti tenaga kerja, nilai tambah, pendapatan atau output. Pendekatan kedua adalah pergeseran struktur perekonomian modifikasi Arcelus. Pendekatan inilah yang digunakan dalam penelitian ini, dimana selain variabel wilayah seperti tenaga kerja, nilai tambah, pendapatan atau output, juga dimasukan unsur dampak pertumbuhan internal dalam struktur perekonomian. Pendakatan Arcelus ini sudah dilakukan oleh Pertiwi (2015), dimana di Kota Surakarta terjadi transformasi ekonomi dari sektor pertanian ke sektor sekunder (industry). Pada kota ini sektor unggulan yang menyerap tenaga banyak adalah sektor industri. Pada sektor pertanian di Kota ini mulai terjadi pergeseran tenaga kerja dan nilai tambah dari sektor pertanian ke sektor industri. Salah satu hal yang harus diperhatikan Pemerintah Kota Surakarta dalam hal keamanan pangan, karena adanya pergeseran struktur perekonomian ini.

Menurut Bendavid-Val dalam Situmorang (2008), bentuk umum persamaan dari analisis pergeseran struktur ekonomi dan komponenkomponennya adalah.

$$
D_{i j}=N_{i j}+M_{i j}+C_{i j}
$$

Keterangan/Remaks:

$i=$ Sektor-sektor ekonomi yang dipilih/ Choissen economic sector

$j \quad=$ Variabel wilayah/Regional variable

$D_{i j} \quad=$ Perubahan sektor $i$ /Sector change condition $i$

$N_{i j} \quad=$ Pertumbuhan nasional sektor $i /$ National growth sector $i$

$M_{i j} \quad=$ Bauran industry dan jasa/ Mixed industri

$C_{i j} \quad=$ Keunggulan kompetitif sektor $i$ di daerah/ Competitive excellence $i$ sector at region

Jika kesempatan kerja ditunjukan oleh National Gross Product suatu wilayah, maka rumusnya:

$$
D_{i j}=E_{i j}^{*}-E_{i j}
$$

Keterangan/Remaks:

$E_{i j}^{*} \quad=$ Kesempatan kerja sektor $i$ di wilayah $\mathrm{i} /$ Job opportunities i sector et region $i$

$E_{i j} \quad=$ Kesempatan kerja sektor $i$ di wilayah $j$ / Job opportunities $j$ sector et region $j$

Jika kesempatan kerja tumbuh sesuai dengan laju pertumbuhan nasional maka komponen pertumbuhan nasional suatu sektor di suatu wilayah dapat ditulis: 


$$
N_{i j}=E_{i j}-r_{n}
$$

Keterangan/Remaks:

$r_{n} \quad=$ Laju pertumbuhan nasional/National growth rate

Komponen keunggulan kompetitif industri atau jasa pada suatu wilayah tumbuh sejalan dengan laju selisih pertumbuhan sektor industri/ jasa tersebut, dimana dapat ditulis:

$$
\begin{aligned}
& M_{i j}=E_{i j}\left(r_{i n}-r_{n}\right) \\
& C_{i j}=E_{i j}\left(r_{i j}-r_{i n}\right)
\end{aligned}
$$

Keterangan/Remaks:

$r_{n} \quad=$ Laju pertumbuhan regional/Regional growth rate

$r_{\text {in }} \quad=$ Laju pertumbuhan sektor i/ pada lokal $j /$ $i$ sector growth rate et local $j$

\section{HASIL DAN PEMBAHASAN}

\section{Penelitian Sebelumnya Mengenai Analisis Pergeseran Struktur Perekonomian}

Hasil penelitian sebelumnya yang menggunakan shift share sudah banyak dilakukan oleh penulis lain baik pada sektor primer, sekunder, maun pun tersier. Pada sektor primer misalnya, penelitian ini pernah dilakukan oleh Huda (2015), dimana peneliti mengkaji sub sektor perikanan di Jawa Timur menggunakan analisis pergeseran struktur perekonomian. Adapun hasil analisis dari penelitian tersebut mengindikasikan bahwa sub sektor perikanan di Wilayah Jawa Timur memiliki keunggulan kompetitif.

Pada sektor primer perikanan lainnya penelitian pernah dilakukan oleh Ismail (2007). Ismail (2007) melakukan penelitian di Halmera, dimana hasil analisis mengindikasikan keunggulan kompepetitif sub sektor perikanan dibawah sektor lainnya. Akan tetapi sub sektor perikanan memiliki keunggulan komaparatif.

Pada sektor tersier, metode ini pernah diaplikasikan oleh (Mira, 2013). Penelitian ini dilakukan pada Kepulauan Seribu, hasil analisis mengindikasikan Kepulauan Seribu memiliki keunggulan komparatif di sub sektor pariwisata. Selain itu, telah terjadi pergeseran struktur perekonomian dari sub sektor primer (perikanan) ke sub sektor tersier (wisata). Hasil penelitian
Mira \& Witomo, 2016) mengindikasikan juga bahwa sub sektor wisata bahari memiliki keunggulan komparitif di Sumbawa dan tidak memiliki keunggulan komparatif di Brebes.

\section{Keunggulan Komparatif dan Komponen Pertumbuhan Sektor Perikanan dan Pariwisata Bahari}

Pada sub bab ini akan dibahas mengenai keunggulan komparatif sektor yang diindikasikan dengan nilai komponen pangsa wilayah dan percepatan/perlambatan suatu sektor yang diindikasikan dengan nilai komponen proporsional. Jika dilihat dari nilai komponen pangsa wilayah, terindikasi bahwa sub sektor perikanan dan sub sektor wisata tidak memiliki keuggulan komparatif/ daya saing. Meskipun Belitung memiliki potensi di sub sektor ini, tapi jika dibandingkan dengan wilayah di atasnya, seperti Propinsi Bangka Belitung atau dengan Bali, maka pertumbuhan dua sub sektor ini masih ketinggalan. Sub sektor perikanan dan wisata tidak memiliki keunggulan komparatif karena nilai pertumbuhan pangsa wilayahnya bernilai negatif.

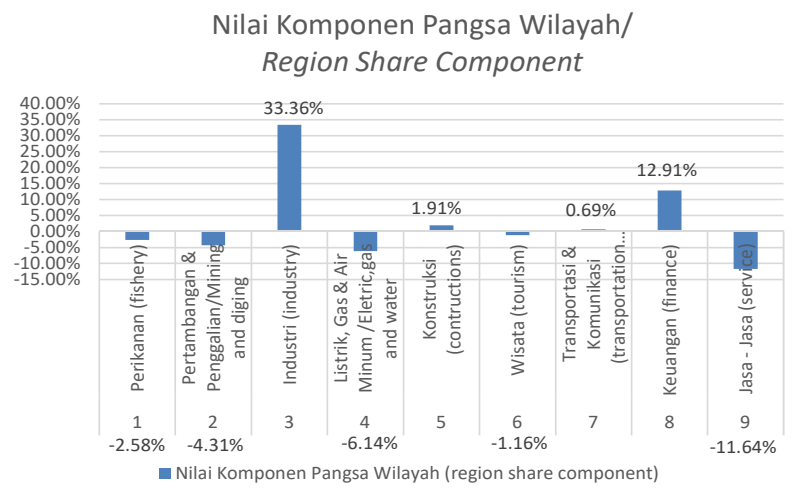

Gambar 1. Nilai Komponen Pangsa Wilayah Sub Sektor Perikanan dan Pariwista Bahari di Belitung.

Figure 1. Value of Region Share Component of Fishery and Tourism Sub Sectors in Belitung.

Jika dilihat secara keseluruhan sektor, sektor yang memiliki keunggulan komparatif dan daya saing adalah sektor industri, keuangan, kontruksi, transportasi dan komunikasi, dimana masing-masing nilai komponen pangsa wilayahnya adalah $33,36 \%, 12,91 \%, 1.91 \%$, dan $0,69 \%$. Sektor yang memiliki daya saing cukup tinggi adalah sektor sekunder dalam hal sektor industri, dimana nilai komponen pangsa wilayahnya yang paling tinggi. 
Dapat ditarik kesimpulan sektor yang mengalami keunggulan komparatif dan daya saing adalah sektor sekunder (industry, kontruksi, transportasi, komunikasi) dan sektor tersier (jasa keuangan). Sedangkan sektor yang tidak memiliki keuggulan komparatif adalah sektor jasa, listrik dan gas, pertambangan, perikanan, dan wisata, dimana masing-masing nilai komponen pangsa wilayahnya adalah - $11,64 \%,-6,14 \%,-4,31 \%$, $-2,58 \%$, dan $-1,16 \%$.

Sedangkan sektor yang tidak memiliki keunggulan komparatif dan tidak memiliki daya saing adalah sektor primer (perikanan, pertambangan) dan sektor sekunder (pertambangan, listrik dan gas), dan sektor jasa (wisata dan jasa lainnya). Sektor yang tidak memiliki keunggulan komparatif atau daya saing karena terindikasi menggunakan bahan baku impor dominan ketimbang menggunakan bahan baku dari domestik. Artinya, komoditi yang diekspor memiliki kerugian obsolut yang dominan, dimana komoditi tersebut komponennya terbuat dari bahan baku ekspor.

Sub sektor perikanan tidak memiliki keunggulan komparatif di Kabupaten Belitung, karena yang berkembang adalah perikanan tangkap yang bahan baku komponen utamanya adalah Bahan Bakar Minyak (BBM). Di Indonesia, BBM dominan masih menggunakan bahan baku impor. Sedangkan untuk sektor wisata tidak memiliki daya saing di Belitung, karena sektor ini baru berkembang di Belitung. Sektor wisata berkembang di Belitung semenjak ada film Laskar Pelangi, sebelumnya wisatawan masih melirik Bali dan Lombok sebagai destinasi tujuan wisata.

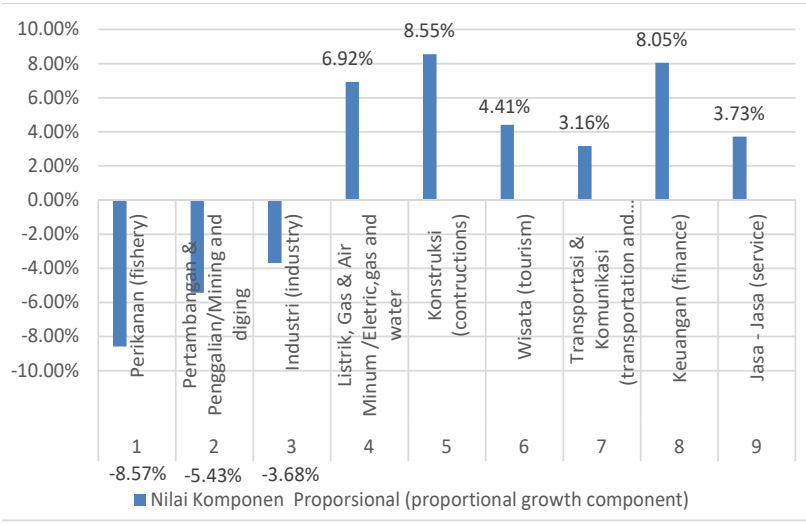

Gambar 2. Nilai Komponen Proporsional Sub Sektor Perikanan dan Pariwista Bahari di Belitung.

Figure 2. Value of Proportional Growth Component of Fishery and Tourism Sub Sectors in Belitung.
Pada Gambar 2 terindikasi bahwa sektor wisata meski tidak memiliki daya saing, tapi mengalami percepatan pertumbuhan, yakni sebesar $4,41 \%$. Hal ini mengindikasikan bahwa sektor wisata merupakan sektor yang mulai berkembang di Belitung. Kontribusi sektor wisata bahari terhadap PDRB Kabupaten Belitung sebesar 3,22\%, dimana $2.98 \%$ dari nilai tambah usaha restaurant dan $0,24 \%$ dari usaha akomodasi.

Secara keseluruhan sektor wisata bahari, mencatat laju pertumbuhan posisif sebesar $6.65 \%$ pada tahun 2014, dan mengalami perlambatan dibanding tahun sebelumnya yang bertumbuh sebesar $8.01 \%$. Perlambatan pertumbuhan inilah yang menyebabkan sektor wisata bahari tidak memiliki daya saing dan keunggulan komparatif. Perlambatan pertumbuhan dipicu oleh kebijakan penghematan anggaran yang dicanangkan oleh Presiden Jokowi, sehingga terjadi perlambatan pada sub sektor akomodasi yang dibelanjakan oleh Pemerintah. Sedangkan untuk kategori restaurant tidak terjadi perlambatan, malah semakin meningkat seiring dengan banyaknya wisatawan yang berkunjung ke Belitung, dimana bertumbuh sebesar $6,87 \%$.

Sektor lain yang mengalami percepatan pertumbuhan yang diindikasikan dengan nilai komponen proporsional yang positif, yaitu sektor yang bersifat sekunder dan tersier, seperti sektor listrik, gas, air, kontruksi, transportasi dan komunikasi, keuangan dan jasa. Terjadinya percepatan pertumbuhan pada sektor listrik dan gas terindikasi peningkatan nilai tambah yang dihasilkan oleh sektor ini. Nilai tambah atas dasar harga berlaku untuk kontribusi sektor listrik dan gas adalah sebesar Rp7.83 miliar, dari kontribusi tersebut $23,52 \%$ digunakan untuk pengadaan gas dan produksi es. Semakin banyaknya kebutuhan es balok untuk usaha perikanan mendorong peningkatan nilai tambah pada sektor listrik dan gas.

Peningkatan nilai tambah pada sektor listrik dan gas ini tercermin dari nilai komponen proporsionalnya yang lumayan tinggi yaitu sebesar $6,92 \%$, artinya terjadi percepatan pertumbuhan sebesar $6,92 \%$ ketimbang tahun sebelumnya. Akan tetapi peningkatan kebutuhan es balok yang mendorong percepatan pertumbuhan pada sektor listrik, gas, dan air belum mampu mendorong percepatan pertumbuhan pada sub sektor perikanan. Bahkan sub sektor ini mengalami perlambatan pertumbuhan yang paling 
tinggi sebesar $-8,57 \%$. Perlambatan pertumbuhan pada sub sektor ini perikanan karena salah satu komoditas unggulan dari Belitung, yaitu ikan asin, mengalami penurunan produksi akibat musim barat yang lebih panjang yang berakibat pada kurangnya jumlah penangkapan teri (DKP, 2016). Selain itu musim barat yang panjang, yang artinya terjadi pada musim hujan menyebabkan proses pengeringan ikan asin terkendala. Selain sub sektor perikanan yang mengalami perlambatan pertumbuhan, ada juga sektor lain yang mengalami hal yang sama, yaitu pertambangan $(-5,43 \%)$ dan sektor industri $(-3,68 \%)$.

\section{Pergeseran Bersih Sub Sektor Perikanan dan Pariwisata Bahari}

Pergeseran bersih sub sektor perikanan dan pariwisata bahari dijabarkan pada pengelompokan sektor. Pada pengelompokan sektor ini akan membahas sektor yang termasuk pada kategori progresif, yaitu sektor yang masuk kategori pertumbuhan maju, dan sektor yang masuk pada kategori yang mengalami perlambatan pertumbuhan. Suatu sektor dimasukan pada kategori progresif bila memiliki nilai pergeseran positif, sebaliknya sektor yang masuk pada kategori yang mengalami perlambatan bila mempunyai nilai pergeseran bersih yang negatif.

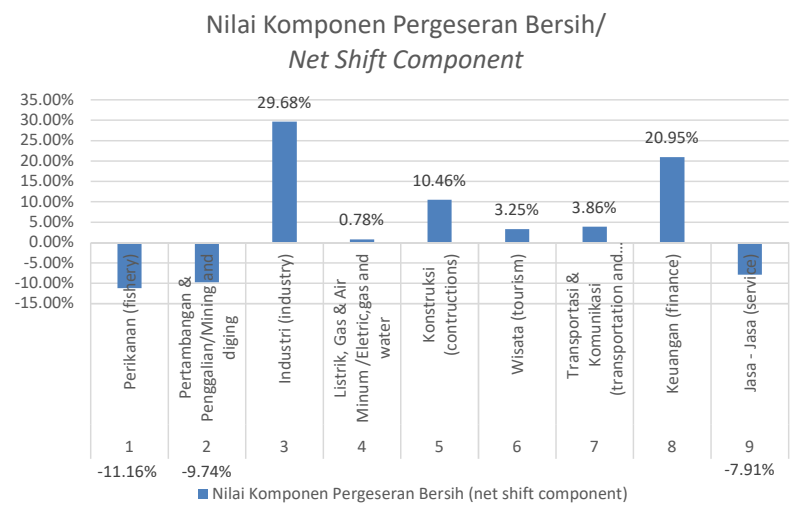

Gambar 3. Nilai Komponen Pergeseran Bersih Sub Sektor Perikanan dan Pariwista Bahari di Belitung.

Figure 3. Value of Net Shift Component of Fishery and Tourism Sub Sectors in Belitung.

Pada wilayah Kabupaten Belitung, sektor yang termasuk pada kategori progresif adalah sektor industri, kontruksi, wisata bahari, transportasi, listrik dan gas dan sektor jasa keuangan. Masing-masing sektor yang mengalami pertumbuhan progresif dari yang tertinggi ke terendah adalah sektor industri
$(29,68 \%)$, keuangan $(20,95 \%)$, kontruksi $(10,86 \%)$, transportasi dan komunikasi $(3,86 \%)$, sektor wisata bahari $(3,25 \%)$, dan sektor listrik, gas, dan air $(0,78 \%)$.

Berdasarkan PDRB Belitung (BPS, 2017), pada sektor industri yang menyumbang peranan cukup besar adalah industri makanan dan minuman $(46,14 \%)$. Sub kategori industri pengolahan menyumbang $6.19 \%$ terhadap pembentukan PDRB, dimana pertumbuhannya cenderung stabil sekitar 6\% tiap tahun sejak tahun 2010. Sub Sektor wisata bahari termasuk pada kategori sektor progresif. Berdasarkan hasil wawancara dengan Bidang Ekonomi Bappeda Belitung, sub sektor wiasata bahari berkembang seiring meningkatnya arus wisatawan yang berkunjung ke Belitung.

Perkembangan sektor wisata memberikan multiplier effect pada sektor lain, misal pada sektor kontruksi, selama dalam kurun waktu lima tahun (2010- 2014), terjadi peningkatan nilai tambah yang signifikan. Pada tahun 2010, nilai tambah sektor ini hanya Rp405 miliar, dan meningkat secara tajam menjadi Rp674 miliar pada tahun 2014. Peningkatan nilai tambah pada sektor kontruksi ditenggarai salah satunya karena dipicu oleh pembangunan hotel dan restaurant sebagai jawaban atas peningkatan kunjungan wisatawan. Bahkan sektor kontruksi mengalami percepatan pertumbuhan yang paling tinggi karena nilai komponen proporsionalnya yang paling tinggi $(8,55 \%)$.

Berdasarkan BPS (2017), multiplier effect lain dari perkembangan sektor wisata bahari di Belitung adalah peningkatan kontribusi sektor transportasi pada pembentukan PDRB Kabupaten Belitung. Dalam durasi waktu 5 tahun, kontribusi sektor transportasi mengindikasikan peningkatan yang signifikan. Pada tahun 2014 kontribusi sektor ini terhadap pembentukan PDRB sebesar $6,24 \%$, padahal tahun sebelumnya hanya $6,17 \%$, dimana kontribusi terbesar disumbangkan oleh sub sektor transportasi udara $(46,13 \%)$ dan transportasilaut(23,58\%). Semakin berkembangnya sektor wisata bahari mendorong peningkatan nilai tambah pada sektor transportasi.

Sektor yang mengalami perlamnbatan pertumbuhan adalah sub sektor perikanan $(-11,16 \%)$, sektor pertambangan dan penggalian $(-9,74 \%)$, dan sektor jasa $(-7,91 \%)$. Sektorsektor yang mengalami perlambatan merupakan sektor-sektor yang sebelumnya menjadi andalan 
perekonomian Kabupaten Belitung (sektor pertambangan dan sektor penggalian). Meskipun sektor perikanan primer memiliki nilai komponen pergeseran bersih yang paling besar $(-11,16 \%)$. Akan tetapi pada sektor sekunder yaitu olahan ikan mengalami peningkatan yang signifakan.

Hal ini mengindikasikan sektor perikanan yang berkembangnya awalnya adalah sektor primer (penangkapan dan budidaya), sekarang beralih yang berkembangan adalah sektor sekunder perikanan (ikan olahan dan ikan asin). Perkembangan sektor tersier perikanan (industri olahan ikan) didukung oleh tersedianya sebanyak 268 Unit Pengolahan Ikan (UPI) yang tersebar di 5 Kecamatan. Selain itu perkembangan sektor tersier perikanan (olahan ikan) juga didukung oleh adannya 19 perusahaan skala menengah yang menghasilkan produk perikanan seperti fillet ikan, olahan daging kepiting/ rajungan, dan daging beku ikan. Sedangkan untuk produk ikan olahan seperti bakso ikan, kerupuk ikan, abon ikan, ikan asin, terasi, dan keripik ikan diproduksi oleh home industry.

\section{Rasio Indikator Sub Sektor Perikanan dan Pariwisata Bahari}

Pada sub bab ini dibahas mengenai rasio pertambahan pertumbuhan yang merupakan indikator suatu sektor masuk pada sektor yang produktif atau tidak produktif, dan juga merupakan suatu indikator suatu sektor yang potensial atau tidak potensialdalam suatu wilayah. Pada Gambar 4 nilai laju pertumbuhan semua sektor adalah positif, artinya pertama semua sektor di Kabupaten Belitung mengalami pertambahan pertumbuhan. Kedua, semua sektor di Kabupaten Belitung masuk pada sektor yang potensial, termasuk sub sektor perikanan dan sub sektor pariwisata bahari. Ketiga, semua sektor di Kabupaten Belitung masuk pada sektor yang produktif.

Jika dilihat dari nilai rasio pertambahan pertumbuhan, sektor yang memiliki pertambahan pertumbuhan paling besar adalah sektor industry $(147 \%)$. Sedangkan sektor yang mengalami pertumbuhan paling kecil adalah sektor jasa $(102 \%)$. Sektor pariwisata bahari mengalami pertambahan pertumbuhan cukup besar yaitu sebesar $113 \%$, sedangkan sub sektor perikanan mengalami pertambahan pertumbuhan sebesar $112 \%$. Artinya, sub sektor perikanan dan pariwisata bahari termasuk pada sektor yang produktif dan potensial. Jika dilihat nilai dari nilai pertambahan pertumbuhan semua sektor yang tidak begitu jauh dari nilai rata-rata pertumbuhan $(117 \%)$, terindikasi tidak ada ketimpangan sektor.

Nilai laju pertumbuhan/Growth Rate

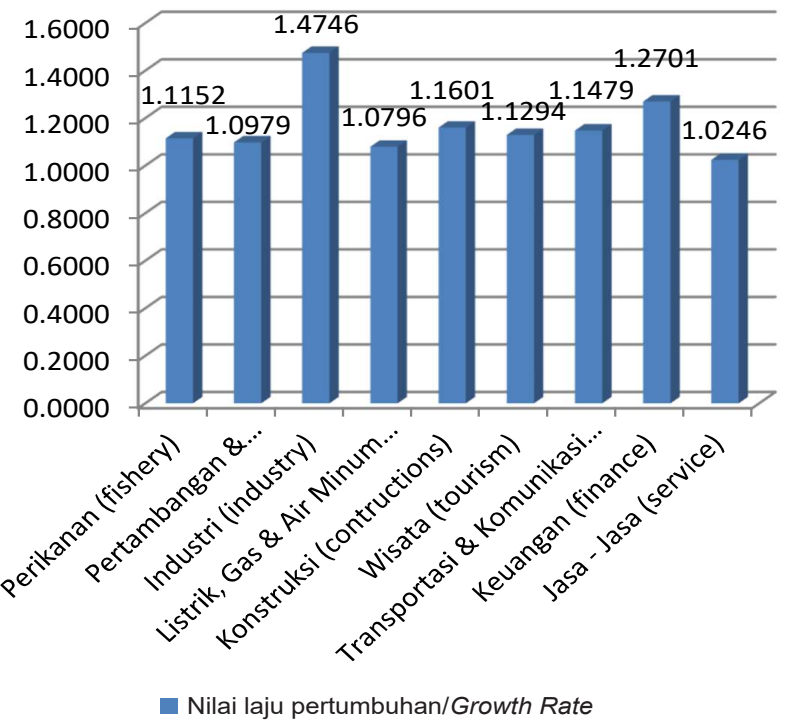

Gambar 4. Nilai Laju Pertumbuhan Perikanan dan Pariwisata Bahari di Kabupaten Belitung.

Figure 4. Growth Rate of the Fisheries and Marine Tourism in Belitung Regency.

Pertambahan pertumbuhan sektor industry yang paling besar tergambarkan dari nilai tambah sektor industri. Komoditi utama yang memiliki nilai tambah cukup tinggi pada kategori industri makanan adalah Crude Palm Oil (CPO), ikan asin, ikan fillet, maupun ikan beku yang diekspor ke luar propinsi dan manca negara. Selain itu ada industri olahan ikan yang mendukung sektor wisata yaitu kerupuk ikan, otak-otak, dan olahan dari rajungan yang dijadikan oleh-oleh wisatawan. Pengiriman ikan ke luar daerah Kabupaten Belitung tahun 2015 adalah 3.500.226 Kg, sedangkan ekspor ikan sebesar 748,55 ton, dimana negara tujuan ekspor adalah Singapura dan Malaysia.

Dinas Kelautan dan Perikanan Kabupaten Belitung melakukan pengembangan dan pembinaan pengolahan hasil perikanan dengan mengoptimalkan operasional UPTD Pengolahan Hasil Perikanan Tanjung Binga. UPTD ini dibangun tahun 2006, dimana fungsinya adalah melakukan pembinaan pengolahan hasil perikanan dan melakukan pemasaran dan standarisasi terhadap olahan hasil ikan. Produk ikan olahan yang dijadikan oleh-oleh wisatawan adalah teri krispi, 
pilus rumput laut, abon ikan, dan olahan rajungan. Berkembangnya sektor wisata bahari membawa dampak positif bagi perkembangan industri olahan ikan. Total produksi olahan ikan meningkat dari $118.433,57 \mathrm{Kg}$ menjadi $226.626,4 \mathrm{Kg}$ pada tahun 2015.

Jika dilihat dari nilai rasio pertambahan pertumbuhan, sektor yang memiliki pertambahan pertumbuhan paling besar adalah sektor industry $(147 \%)$. Sedangkan sektor yang mengalami pertumbuhan paling kecil adalah sektor jasa (102\%). Sektor pariwisata bahari mengalami pertambahan pertumbuhan cukup besar yaitu sebesar $113 \%$, sedangkan sub sektor perikanan mengalami pertambahan pertumbuhan sebesar $112 \%$. Artinya, sub sektor perikanan dan pariwisata bahari termasuk pada sektor yang produktif dan potensial. Jika dilihat nilai dari nilai pertambahan pertumbuhan semua sektor yang tidak begitu jauh dari nilai rata-rata pertumbuhan (117\%), terindikasi tidak ada ketimpangan sektor.

Pertambahan pertumbuhan sektor industry yang paling besar tergambarkan dari nilai tambah sektor industri. Komoditi utama yang memiliki nilai tambah cukup tinggi pada kategori industri makanan adalah Crude Palm Oil (CPO), ikan asin, ikan fillet, maupun ikan beku yang diekspor ke luar propinsi dan manca negara. Selain itu ada industri olahan ikan yang mendukung sektor wisata yaitu kerupuk ikan, otak-otak, dan olahan dari rajungan yang dijadikan oleh-oleh wisatawan. Pengiriman ikan ke luar daerah Kabupaten Belitung tahun 2015 adalah 3.500.226 $\mathrm{Kg}$, sedangkan ekspor ikan sebesar 748,55 ton, dimana negara tujuan ekspor adalah Singapura dan Malaysia.

Dinas Kelautan dan Perikanan Kabupaten Belitung melakukan pengembangan dan pembinaan pengolahan hasil perikanan dengan mengoptimalkan operasional UPTD Pengolahan Hasil Perikanan Tanjung Binga. UPTD ini dibangun tahun 2006, dimana fungsinya adalah melakukan pembinaan pengolahan hasil perikanan dan melakukan pemasaran dan standarisasi terhadap olahan hasil ikan. Produk ikan olahan yang dijadikan oleh-oleh wisatawan adalah teri krispi, pilus rumput laut, abon ikan, dan olahan rajungan. Berkembangnya sektor wisata bahari membawa dampak positif bagi perkembangan industri olahan ikan. Total produksi olahan ikan meningkat dari $118.433,57 \mathrm{Kg}$ menjadi 226.626,4 Kg pada tahun 2015.

\section{Kuadran Profil Pertumbuhan Sub Sektor Perikanan dan Pariwisata Bahari}

Pada sub bab ini akan dibahas profil suatu sektor yang digambarkan dalam bentuk kuadran. Profil tersebut tersebar dalam 4 kuadran, yaitu kuadran satu meliputi sektor keuangan, kontruksi, dan sektor transportasi. Hal ini mengindikasikan sektor keuangan, kontruksi, dan sektor transportasi masuk pada sektor unggulan. Sedangkan sektor yang termasuk pada sektor kuadran kedua hanya sektor industri. Sektor yang termasuk pada kuadran kedua termasuk pada sektor agak unggul. Artinya, sektor industri termasuk pada sektor agak unggul, meskipun sektor industri memiliki nilai tambah besar, akan tetapi sektor industri baru mulai berkembang di Belitung, yang sebelumnya mengandalkan sektor pertambangan dan perikanan. Selain itu terjadi perlambatan pada sektor industri.

Sedangkan perlambatan pertumbuhan pada sektor industry karena terjadinya penurunan daya beli masyarakat (BPS, 2017). Lesunya aktivitas dibidang pertambangan, menyebabkan pendapatan msyarakat menurun, yang pada akhirnya menurunkan daya beli masyarakat. Penurunan daya beli selama kurun waktu 5 tahun terakhir (semenjak tahun 2010) sangat terlihat pada sektor perdagangan, dimana pada tahun 2014 hanya mencatat pertumbuhan sebesar 4,34 persen, tahun sebelumnya mencapai $4,76 \%$.

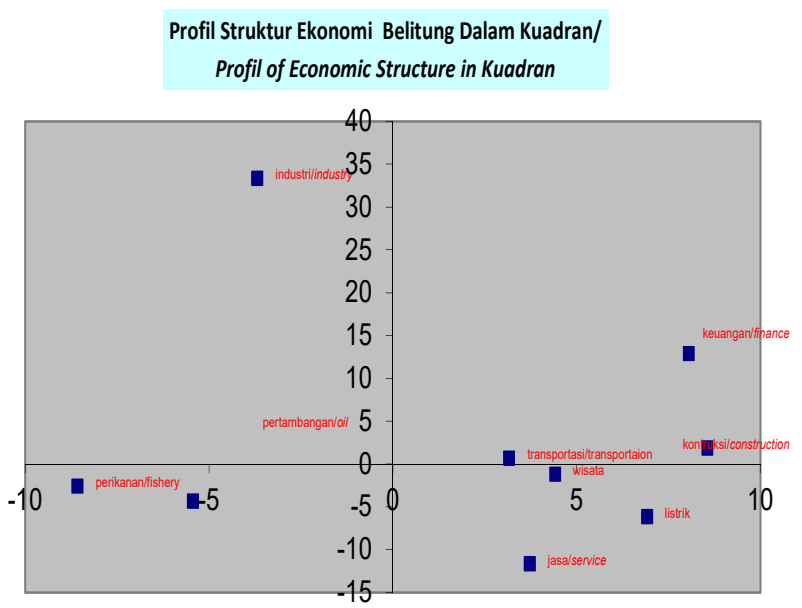

Gambar 5. Profil Pertumbuhan Perikanan dan Pariwisata Bahari dalam Struktur Ekonomi Belitung.

Figure 5. Profile of Fisheries and Marine Tourism Growth in the Economic Structure of Belitung. 
Sektor yang termasuk pada kuadran ketiga adalah sektor wisata, listrik, dan jasa. Sektor ini termasuk sektor agak mundur. Sektor wisata mengalami kemunduran karena terjadi perlambatan pertumbuhan sebesar -1,36 persen. Perlambatan pertumbuhan terjadi karena kebijkan penghematan anggaran oleh Pemerintah, dimana adanya pembatasan mengadakan pertemuan dan rapat menggunakan akomodasi hotel yang dikelola oleh swasta.

Sektor yang termasuk pada kuadran terakhir atau kuadran keempat adalah sektor perikanan dan pertambangan. Artinya kedua sektor ini termasuk pada sektor yang mundur. Perlambatan pertumbuhan pada sektor pertambangan terjadi karena dari sisi permintaan bahan baku indutri logam timah mengalami penurunan. Selain itu sektor pertambangan timah di Belitung terkena isu kerusakan lingkungan terkait kegiatan penambangan dan menurunnya cadangan timah. Penurunan nilai tambah sektor pertambangan sudah dimulai sejak tahun 2010, dimana pada tahun 2010 kontribusi sektor ini mencapai 55,46\%. Pada tahun 2014 kontribusi sektor ini hanya 48,61\% terhadap PDRB.

\section{KESIMPULAN DAN REKOMENDASI KEBIJAKAN}

\section{Kesimpulan}

Pertama, sektor yang memiliki keunggulan komparatif dan daya saing adalah sektor industri, keuangan, kontruksi, transportasi dan komunikasi, dimana diindikasikan dengan nilai komponen pangsa wilayahnya yang positif. Masing-masing sektor yang memiliki keunggulan komparatif memiliki nilai komponen pangsa wilayah sebesar $33,36 \%, 12,91 \%, 1.91 \%$, dan 0,69\%. Sedangkan sektor yang tidak memiliki keunggulan komparatif dan daya saing adalah sektor jasa, listrik dan gas, pertambangan, perikanan, dan wisata, masingmasing nilai komponen pangsa wilayahnya adalah - 11,64\%, - 6,14\%, -4,31\%, - 2,58\%, dan $-1,16 \%$. Sektor tersebut tidak memiliki keunggulan komparatif karena memiliki nilai nilai komponen pangsa wilayah yang negatif.

Kedua, sektor yang mengalami pertumbuhan progresif adalah industri $(29,68 \%)$, keuangan $(20,95 \%)$, kontruksi $(10,86 \%)$, transportasi dan komunikasi $(3,86 \%)$, sektor wisata bahari $(3,25 \%)$, dan sektor listrik, gas, dan air $(0,78 \%)$. Pertumbuhan sektor yang positif diindikasikan dengan nilai pergeseran bersih yang positif. Sedangkan sektor yang pertumbuhannya melambat adalah sub sektor perikanan $(-11,16 \%)$, sektor pertambangan dan penggalian $(-9,74 \%)$, dan sektor jasa $(-7,91 \%)$. Perlambatan pertumbuhan terjadi pada sektor yang sebelumnya menjadi tumpuan perekonomian Belitung (pertambangan dan perikanan).

Ketiga, rasio indikator pertambahan pertumbuhan masing-masing sektor adalah industry (147\%), keuangan (127\%), kontruksi (116\%), transportasi dan komunikasi (115\%), wisata $(113 \%)$, perikanan $(112 \%)$, pertambangan dan penggalian(110\%), listrik dan gas (108\%), dan jasa (102\%). Artinya, semua sektor termasuk pada sektor yang produktif dan potensial dan tidak terjadi ketimpangan sektor.

Keempat, profil sektor dalam kuadran menyebar dari kuadra 1,2,3,dan 4. Pada kuadran 1. ada sektor keuangan, kontruksi, dan sektor transportasi yang mengindikasikan sektor tersebut sektor unggulan. Pada kuadran 2 hanya ada sektor industri, artinya sektor industri adalah sektor agak unggul. Pada kuadran 3, ada sektor sektor wisata, listrik, dan jasa, yang mengindikasikan sektor ini termasuk pada sektor agak mundur. Pada kuadran 4, ada sektor perikanan dan pertambangan yang kedua sektor ini termasuk pada sektor yang mundur.

\section{Rekomendasi Kebijakan}

Dalam teori pergeseran struktur perekonomian dalam suatu wilayah, sektor yang termasuk pada kuadran keempat atau sektor mengalami kemunduran, terjadi karena pergeseran perekonomian. Di Belitung terjadi pergeseran perekonomian, yang awalnya perekonomian Belitung pada sektor pertambangan dan perikanan dan beralih ke sektor industri dan sektor pariwisata. Dalam teori pergeseran perekonomian lumrah ditemuai dalam suatu wilayah terjadi pergeseran tumpuan perekonomian wilayah dari sektor primer ke sektor industri dan jasa.

Hal yang perlu dilakukan Pemerintah daerah adalah pertama: mengimplementasikan penambangan yang berkelanjutan dan ramah lingkungan. Kedua: mata pencarian alternatif selain sektor pertambangan. Salah satu sektor yang menjadi mata pencarian alternative masyarakat adalah sektor wisata. Masyarakat yang sebelumnya melakukan pertambangan konvensional mulai melakukan usaha rental motor, mobil, dan bahkan ada yang yang terjun ke usaha home stay atau usaha restoran. 
Salah satu yang menjadi kendala dalam peralihan sumber mata pencarian ini adalah perbedaan orientasi usahanya. Masyarakat yang sebelumnya tergantung pada usaha ekstrasi sumberdaya, sekarang dihadapkan pada peralihan usaha pada sektor wisata yang merupakan usaha jasa. Perbedaan itu terlihat pada usaha jasa yang membutuhkan pelayanan, sedangkan usaha pada sektor pertambangan hanya membutuhkan tenaga fisik. Peralihan mata pencarian itu tidak hanya pada sektor pertambangan saja, juga pada sektor perikanan. Nelayan yang sebelumnya menggunakan kapalnya untuk menangkap ikan, sekarang banyak menyewakan perahu untuk mengantar pengunjung ke Pulau sekitar Belitung.

\section{UCAPAN TERIMA KASIH}

Terima kasih kami ucapkan Pada Sumber acuan kami dan pihak pihak yang telah bersedia memberikan data, seperti Biro Pusat Statistik Bangka Belitung, Bappeda Belitung, Dinas Kelautan dan Perikanan, dan Dinas Pariwisata Belitung.

\section{DAFTAR PUSTAKA}

Abidin, Z. (2015). Aplikasi Analisis Shift Share Pada Transformasi Sektor Pertanian Dalam Perekonomian Wilayah di Sulawesi Tenggara. Jurnal Informatika Pertanian 24 (2): 165-178.

Abdillah, D. (2016). Pengembangan Wisata Bahari Di Pesisir Pantai Teluk Lampung. Jurnal Destinasi Kepariwisataan Indonesia 1 (1): 45-65.

Badan Pusat Statistik. (2017). PDRB Belitung Menurut Lapangan Usaha. Badan Pusat Statistik Kabupaten Belitung. Belitung.

Budianto, P.F., Susilo, E. \& Indrayani. (2013). Implementasi Pengembangan Pariwisata DiPulau-Pulau Kecil Terhadap Masyarakat Pesisir Desa Lihunu, Kecamatan Likupang, Kabupaten Minahasa Utara, Provinsi Sulawesi Utara. Jurnal Eksofim 1 (1): 1-10.

Dinas Kelautan dan Perikanan. (2016). Laporan Tahun DKP Kabupaten Belitung. Belitung.

Hasani, A. (2010). Analisis Struktur Perekonomian Berdasarkan Pendekatan Shift Share di Propinsi Jawa Tengah Tahun 2003 dan Tahun 2008. Skripsi. Fakultas Ekonomi Universitas Diponegoro. Semarang.

Hustin, V.J. (2017). Pengembangan Potensi Wisata Bahari Dalam Meningkatkan Ekonomi Maritim Menuju Indonesia Sebagai Poros Maritim Dunia. Jitunews.com.diakses tanggal 1 Maret 2018.
Huda. H.M. 2015. Pembangunan Perikanan Dalam Kerangk Pengembangan Ekonomi Wilayah di ProvinsiJawa Timur. Sekolah Pasca Sarjana Institut Pertanian Bogor Jawa Barat. (Tesis).

Ismail. M. R. 2007. Kajian Pengembangan Wilayah Pulau-Pulau Kecil di Kabupaten Halmahera Utara (Tinjauan Terhadap Pengelolaan Sumberdaya Perikanan Cakalang). Sekolah Pasca Sarjana Institut Pertanian Bogor Jawa Barat. (Tesis).

Mudzakir, A. K. (2008). Peranan Sektor Perikanan Pada Perekonomian Jawa Tengah : Pendekatan Model Input Output. Jurnal Saintek Perikanan 4 (8): 28-34.

Mira. (2013). Keunggulan Sub Sektor Perikanan Dan Pariwisata Bahari Dalam Struktur Perekonomian Wilayah Pulau-Pulau Kecil. Jurnal Sosial Ekonomi Kelautan Dan Perikanan 8 (2):145-156.

Mira, \& , C.M. Witomo (2016). Kinerja Sub Sektor Perikanan Dan Pariwisata Bahari Dalam Struktur Perekonomian Wilayah Pesisir. Jurnal Sosial Ekonomi Kelautan Dan Perikanan 11 (1):13-27.

Pertiwi, A.I. (2015). Analisis Struktur Perekonomian Berdasarkan Pendekatan Shift Share di Suarakarta. Skripsi. Fakultas Ekonomi. Universitas Muhamadiyah Surakarta. Surakarta.

Razak, F., Suzana, B.O.L., \& Kapantaouw, G.H.M. (2017). Strategi Pengembangan Wisata Bahari Pantai Malalayang, Kota Manado, Sulawesi Utara. Agri-Sosio Ekonomi 13 (1): 277-284.

Situmorang, Y.P.M. (2008). Analisis Arah Transformasi Struktural Pada Sektor Primer, Sekunder dan Tersier : Pendekatan Estimasi Elastisitas Tenaga Kerja dan Analisis Shift Share, Kasus 5 Kota Besar di Indonesia. Departemen IImu Ekonomi Fakultas Ekonomi Universitas Indonesia. (Skripsi). 180 Halaman.

Todaro, M. \& Smith, S. (2004). Pembangunan Ekonomi di Dunia Ketiga. Edisi Kedelapan.Jakarta. Erlangga. 